\title{
Amsacta moorei Entomopoxvirus Encodes a Functional Esterase (amv133) with Protease Activity
}

\author{
Emine Özşahin Kazım Sezen Zihni Demirbağ \\ Department of Biology, Faculty of Science, Karadeniz Technical University, Trabzon, Turkey
}

\section{Key Words}

Amsacta moorei entomopoxvirus · Lipase · Esterase ·

Protease $\cdot$ amv 133 conserved gene in all entomopoxvirus genomes sequenced so far and might contribute greatly to degrading the lipids or proteins and hence improve the virus infection.

(C) 2015 S. Karger AG, Basel

\begin{abstract}
Objectives: Lipolytic genes have been investigated in several viral genomes, and some of them show enzyme activity which can be used for various functions including the production of DNA replication metabolites, rescue from endosomes, and membrane fusion. Amsacta moorei entomopoxvirus (AMEV) replicates in nearly the entire insect body, especially in the adipose tissue. One of the open reading frames (ORFs) in the AMEV genome, amv133, encodes a putative lipase enzyme. In this study, we therefore investigate the enzyme activity of amv133. Methods: amv133 was aligned with known lipase genes and their homologs in entomopoxviruses. Expressed proteins were partially purified and assayed for lipase, esterase and protease. Results: We found that amv133 contains all the domains required for a functional lipase enzyme and that it shows a significant similarity with homologs in other entomopoxviruses. Since there is a similarity of the catalytic triad between lipases and serine proteases, we also investigated the protease activity of amv133. Lipase, esterase and protease assays showed that amv 133 encodes a functional esterase enzyme with protease activity. Conclusion: The current data show that amv133 is a
\end{abstract}

\section{Introduction}

Amsacta moorei entomopoxvirus (AMEV) is the type species of betaentomopoxvirus encompassing Lepidoptera (moths) and Orthoptera (grasshoppers) [1]. Therefore, AMEV could be used as a microbiological control agent against some harmful insects in agriculture [2]. AMEV is the best and most studied entomopoxvirus because it is one of the few insect poxviruses which can be readily grown and manipulated in tissue culture $[3,4]$. Its replication takes place in various larval tissues, but it prefers fat body cells [5], which are the major site of lipid storage [6]. A complete genome analysis of AMEV showed that it has 232,392 base pairs [7] and contains 294 open reading frames (ORFs) [2]. amv133 is one of the ORFs and encodes a putative triacylglycerol lipase [7].

Lipases (triacylglycerol acylhydrolases; EC 3.1.1.3) and esterases (carboxylic ester hydrolases; EC 3.1.1.1), collectively known as lipolytic enzymes, are characterized by their ability to hydrolyze hydrophobic long- and shortchain carboxylic acid esters [8]. Most of these hydrolases

\section{KARGER 125\%}

(c) 2015 S. Karger AG, Basel

0300-5526/15/0581-0041\$39.50/0

E-Mail karger@karger.com

www.karger.com/int 
contain the consensus sequence Gly-X-Ser-X-Gly (X = any amino acid) around the active site of serine and function via a Ser-Asp-His catalytic triad [9]. Some lipases share a common Ser-Asp/Glu-His catalytic triad with serine proteases $[10,11]$. Some of the serine proteases, such as chymotrypsin and subtilisin, show lipase activity; however, not all lipases tested show serine protease activity, except commercially available porcine pancreatic lipase [11-13].

Lipase-like genes have been found in several viral genomes showing lipase activity, including $p 37$ from vaccinia virus [14], $v p 1$ from adeno-associated virus $[15,16]$ and $v p 1$ from parvovirus $[17,18]$, and they have several different functions, such as facilitating membrane fusion and escape from endosomes. vlip from Marek's disease virus [19] and orf19 from Heliothis virescens ascovirus [20] do not show lipase activity. Ectromelia virus [21] and Melanoplus sanguinipes entomopoxvirus (MSEV) [22] have amv133-similar genes that are thought to play a role in the viral inflammatory response [7]. Furthermore, 5 different entomopoxviruses have homologs to amv133 [2]; however, none of them were characterized as showing lipase-encoding activity or any other type of activity.

Proteases are toxic to insects because they degrade the peritrophic matrix [23], and serine proteases have been shown to increase the viral speed with which the host is killed [24]. amv133 has a catalytic triad of serine proteases.

The importance of lipid metabolism for viral growth and examples of other viral lipase genes suggest that amv133 could be an active lipase gene. Also, because of the similarity of the catalytic triad between serine proteases and lipases, it is thought that amv133 may also show protease activity. In our study, we investigated the lipase, esterase and protease activities of amv133 and found that $a m v 133$ encodes an active esterase with protease activity.

\section{Materials and Methods}

\section{Prediction Studies}

The amino acid sequence of $a m v 133$ was predicted using theExPASy-PROSITE program and aligned with other lipase family members using the MEGA 5.05 and GeneDoc programs.

\section{Virus and Cells}

An aliquot of AMEV and the Lymantria dispar (IPLB-LD-652) cells were kindly provided by Basil Arif (Laboratory for Molecular Virology, Great Lakes Forestry Centre, Canada).

The IPLB-LD-652 cells were maintained in $45 \%$ Excell- 420 (SAFC Biosciences), 45\% Grace's Insect Medium (Gibco), which is serum-free, and $10 \%$ fetal bovine serum (Gibco) at $28^{\circ} \mathrm{C}$. An infection of IPLB-LD-652 cells with AMEV was performed as follows: cells were seeded in T75 tissue culture flasks at $1 \times 10^{5}$ cells/ $\mathrm{cm}^{2}$ and allowed to attach at $28^{\circ} \mathrm{C}$ for $2 \mathrm{~h}$. The medium was removed, and the virus was added at 0.1 multiplicity of infection. The flasks were incubated at $28^{\circ} \mathrm{C}$ and gently rocked for $2 \mathrm{~h}$ to allow for virus attachment. At the end of the incubation period, a fresh culture medium was added and the flasks were incubated at $28^{\circ} \mathrm{C}$ for 5 days. Cells were centrifuged at $1,000 \mathrm{~g}$ for $15 \mathrm{~min}$ to remove cell debris. The titer of enveloped virus stock was determined as described in previous studies [25].

\section{DNA Extraction from AMEV}

In order to extract DNA, IPLB-LD-652 cells were infected with AMEV at 0.1 multiplicity of infection, and the virus was harvested as described above. The virus stock was centrifuged at 18,000 rpm for $30 \mathrm{~min}$. The resulting pellet was dissolved in $9 \mathrm{ml}$ TE buffer (10 mM Tris, $\mathrm{pH} 8$; 1 mM EDTA). $30 \mu \mathrm{l} \beta$-mercaptoethanol, $100 \mu \mathrm{l}$ proteinase $\mathrm{K}, 400 \mu \mathrm{l} 5 \mathrm{M} \mathrm{NaCI}$ and $1 \mathrm{ml} 10 \%$ SDS were added, and the mixture was incubated at $37^{\circ} \mathrm{C}$ for $5 \mathrm{~h}$. Then the mixture was incubated overnight at $4^{\circ} \mathrm{C} .15 \mathrm{ml}$ of phenol:chloroform:isoamyl alcohol $(25: 24: 1)$ was added to the mixture which was then allowed to rotate at the lowest speed in a rotary mixer for $10 \mathrm{~min}$. Then it was centrifuged at $300 \mathrm{~g}$ for $10 \mathrm{~min}$. The supernatant was transferred to a clear tube, and $15 \mathrm{ml}$ of phenol:chloroform:isoamyl alcohol was mixed and centrifuged at the same conditions. Sodium acetate (1/10 volume of $3 \mathrm{M}$ solution, $\mathrm{pH} 7)$ and absolute ethanol (2.5 volume) were added, and the mixture was incubated on ice for $30 \mathrm{~min}$ and then centrifuged at $16,000 \mathrm{~g}$ for $15 \mathrm{~min}$. After drying the pellet, it was dissolved in $200 \mathrm{\mu l} \mathrm{dH}_{2} \mathrm{O}$. The DNA concentration was measured by NanoDrop (Thermo Scientific).

Cloning, Expression and Purification of amv133

$a m v 133$ was amplified directly from the genomic DNA of AMEV using 2 pairs of primers (LIP-NdeI-Fw: $5^{\prime}$-CCATATG ACAATATTTGAAATATTAATATGG-3', LIP-BamHI-Rv: $5^{\prime}$-C GGATCCCTATTAAATTTCTAAATATTTTAG-3'; LIP-BamHIFw: 5'-CGGGATCCACAATATTTGAAATATTAATATGGATA ATTG-3'; LIP-EcoRI-Rv: 5'-CGGAATTCTTAAATTTCTAA ATATTTTAGATTATCAATATTG- $3^{\prime}$ ) designed according to the $a m v 133$ sequence of the AMEV complete genome sequence [7]. $0.5 \mu \mathrm{l}$ Phusion DNA polymerase (NEB, Ipswich, Mass., USA) was used to perform PCR reactions with $10 \mathrm{ng}$ AMEV genomic DNA (260/280 ratio: 1.9 ) as the template and with $10 \mu \mathrm{l} 5 \mathrm{x}$ Phusion HF buffer, $1 \mu \mathrm{l} 10 \mathrm{mM}$ dNTP, $2.5 \mu \mathrm{l} 10 \mu \mathrm{M}$ forward primer, $2.5 \mu \mathrm{l} 10 \mu \mathrm{M}$ reverse primer and $32.5 \mu \mathrm{l}$ nuclease-free water in a final volume of $50 \mu \mathrm{l}$. The PCR conditions were as follows: 1 initial denaturation step at $98^{\circ} \mathrm{C}$ for $30 \mathrm{~s}, 35$ cycles at $98^{\circ} \mathrm{C}$ for $10 \mathrm{~s}$, annealing at $55^{\circ} \mathrm{C}$ for $30 \mathrm{~s}$ and extension at $72^{\circ} \mathrm{C}$ for $30 \mathrm{~s}$, except for the final cycle where the extension proceeded for $5 \mathrm{~min}$. The PCR fragment was cleaned from the agarose gel using the Nucleospin extraction II kit (Machery-Nagel) following the manufacturer's instructions, cloned into pJET1.2 vector (Thermo Scientific) and sequenced (Macrogen).

For the bacterial expression of $a m v 133$, the 864 base pair fragment was released from pJET1.2 and digested with $\mathrm{NdeI}$ and $B a m \mathrm{HI}$ restriction enzymes. Then it was ligated with pET28a(+) (Novagen) and digested with $\mathrm{NdeI}$ and $\mathrm{BamHI}$. The ligation products transformed into Escherichia coli BL21(DE3)pLysS (Novagen). 10 clones were inoculated into $2 \mathrm{ml}$ Luria Bertani (LB) broth
42
Intervirology 2015;58:41-48 DOI: $10.1159 / 000369018$
Özşahin/Sezen/Demirbağ 
medium containing $50 \mathrm{mg} / \mathrm{ml}$ kanamycin and $10 \mathrm{mg} / \mathrm{ml}$ chloramphenicol containing an overnight culture. The overnight cultures were transferred to a 5-ml LB broth medium and the optical density was adjusted to 0.1 at $600 \mathrm{~nm}$. The cultures were grown until $\mathrm{OD}_{600}$ was between 0.3 and 0.5 and induced with isopropyl $\beta$-D-1thiogalactopyranoside at the final concentration of $1 \mathrm{mM}$. After $3 \mathrm{~h}$ of incubation at $30^{\circ} \mathrm{C}$, the cultures were chilled on ice for $30 \mathrm{~min}$, followed by a spindown at $5,000 \mathrm{rpm}$ for $10 \mathrm{~min}$ at $4^{\circ} \mathrm{C}$. The pellets were resuspended in $500 \mu \mathrm{l}$ ice-cold PBS and incubated with $10 \mathrm{mg} / \mathrm{ml}$ lysozyme at $30^{\circ} \mathrm{C}$ for $15 \mathrm{~min}$, followed by sonication with Labsonic M (Sartorius; $80 \%$ amplitude, 0.6 cycle for $5 \mathrm{~min}$ ) to release intracellular proteins. The cell-free extract was centrifuged at $10,000 \mathrm{rpm}$ for $30 \mathrm{~min}$ to remove cell debris. Supernatants were analyzed by Western blot using the anti-His antibody conjugated with alkaline phosphatase. The clone that showed the highest level of expression was used for protein expression in 1 liter LB broth medium using the same procedure as above except for a pellet resuspended in $2 \mathrm{ml}$ ice-cold PBS for activity experiments.

For the baculovirus expression of amv133, the Bac-to-Bac Baculovirus Expression System (Invitrogen) was used. The 864 base pair fragment was released from pJET1.2 digested with BamHI and EcoRI restriction enzymes, and then it was ligated with pFastBacHTB digested with BamHI and EcoRI. The ligation product transformed into $E$. coli JM101 (NEB). pFastBacHTB vectors carrying $a m v 133$ were isolated from one of the positive clones, and then they transformed into $E$. coli $\mathrm{DH} 10 \mathrm{Bac}$ cells to regenerate bacmid expressing amv133 (AmBac133). AmBac133 was confirmed via PCR using a pair of primers, M13Fw and M13Rv, and extracted. Spodoptera frugiperda cells $\left(2 \times 10^{6}\right.$ cells $\left./ \mathrm{ml}\right)$ were transfected with the AmBac133 using Cellfectin (Invitrogen) transfection reagent according to the Bac-to-Bac manual. The transfected cells were incubated at $27^{\circ} \mathrm{C}$ until the cells showed visible signs of infection (usually $72 \mathrm{~h}$ or more). The expression of amv133 was confirmed by Western blot analysis using anti-His monoclonal antibody conjugated with alkaline phosphatase (1:5,000; Sigma). Recombinant baculovirus expressing amv133 (vAmBac133) were amplified using T75 tissue culture flasks, and the virus titer was determined by endpoint dilution assay.

S. frugiperda cells were adapted to suspension culture by the following procedure: $2.5 \times 10^{6} \mathrm{~S}$. frugiperda cells were transferred to a $125-\mathrm{ml}$ Erlenmeyer glass flask together with $20 \mathrm{ml}$ SFM 900 medium containing $5 \%$ fetal bovine serum and incubated at $28^{\circ} \mathrm{C}$ and rocked at $100 \mathrm{rpm}$ for $48 \mathrm{~h}$, after which the cells were subcultured. For protein production, $100 \mathrm{ml}$ of a medium containing $2 \times$ $10^{6}$ cells/ml were infected with vAmBac133 at 5 multiplicity of infection, and cells were harvested $78 \mathrm{~h}$ after infection and washed with PBS containing protease inhibitor solution (Roche). The resulting pellet was frozen at $-80^{\circ} \mathrm{C}$ and resuspended in $5 \mathrm{ml}$ PBS. The protein purification was performed using the MagneHis ${ }^{\mathrm{TM}}$ Protein Purification System (Promega) following the manufacturer's instructions. The protein concentration was determined by Bradford's [26] method with bovine serum albumin as the standard. Extraction was confirmed by Western blot analysis using anti-His monoclonal antibody (1:5,000; Sigma).

Lipase/Esterase Activity Assay

A standard esterase activity assay was performed using $p$-nitrophenyl butyrate $(\mathrm{C} 4)$ as a substrate [27], dissolved in acetonitrile at a concentration of $10 \mathrm{mM}$. To prepare the substrate solution, $p$ nitrophenyl butyrate, ethanol and $50 \mathrm{~mm}$ Tris- $\mathrm{HCl}(\mathrm{pH} 8.0)$, were added to a final composition of 1:4:95 (v/v), respectively. The standard reaction mixture was composed of $900 \mu \mathrm{l}$ substrate solution, $270 \mu \mathrm{l}$ buffer (50 mM Tris- $\mathrm{HCl}, \mathrm{pH} 8.0)$ and $30 \mu \mathrm{l}(1 \mu \mathrm{g})$ purified proteins. The enzyme was replaced with the buffer in cases of a blank. The mixtures were incubated at $28^{\circ} \mathrm{C}$ for $20 \mathrm{~min}$, and then the reactions were stopped by adding $200 \mu \mathrm{l} 10 \%$ SDS solution. The enzyme activity was measured by monitoring the change in absorbance at $405 \mathrm{~nm}$ in a SpectraMax M2 (Molecular Devices) plate reader, representing the amount of released $p$-nitrophenol. The experiment was repeated 3 times.

For the lipase activity assay, previously described methods [28] were used. In brief, $1.5 \mathrm{~g}$ agar was added to $100 \mathrm{ml}$ Tris- $\mathrm{Cl}$ (pH 8.8) along with $8 \mathrm{mg}$ Victoria blue B dye and $1.5 \mathrm{ml}$ of a $20 \%$ olive oil in polyvinyl alcohol ( $2 \%$ polyvinyl alcohol in water) emulsion or triolein (Sigma). The mixture was autoclaved and then poured onto a $35-\mathrm{mm}$ plate. Wells were cut using a rivet sterilized in $100 \%$ ethanol. The concentrations of the samples were adjusted to fall between those of the controls. Each well was loaded and the plate incubated at $28^{\circ} \mathrm{C}$ for $24 \mathrm{~h}$. The experiment was repeated 3 times.

\section{Protease Activity Assay}

Proteolytic activity was assayed according to the method of Murata et al. [29]. In brief, the enzyme solutions or controls (650 ng) were added to $2 \%(\mathrm{w} / \mathrm{v}) 400 \mu \mathrm{l}$ casein solution (dissolved in $200 \mathrm{mM}$ Tris- $\mathrm{HCl}$ buffer, $\mathrm{pH} \mathrm{7)}$ and incubated at $28^{\circ} \mathrm{C}$ for $30 \mathrm{~min}$. The reaction was stopped by adding $440 \mu \mathrm{l} 10 \%$ trichloroacetic acid and allowed to stand for $30 \mathrm{~min}$. The mixture was centrifuged at $1,500 \mathrm{~g}$ for $15 \mathrm{~min}$, and an aliquot $(1 \mathrm{ml})$ was mixed with $2.5 \mathrm{ml}$ of $0.4 \mathrm{M}$ sodium carbonate and $0.5 \mathrm{ml}$ Folin-Ciocalteu reagent 1:2 diluted with water. The assay was read at $660 \mathrm{~nm}$. To inhibit protease activity of amv133, two different conditions were employed before substrate addition: (1) $0.1 \%$ SDS followed by heating at $98^{\circ} \mathrm{C}$ for $1 \mathrm{~h}$, and (2) $1 \mathrm{mM}$ PMSF.

In all the experiments, a nonenzymatic protein, the $337 \mathrm{~L}$ gene from the Chilo iridescent virus expressed in the same vectors, was also purified and the concentration calculated, to be used as a negative control. The experiment was repeated 3 times. The results of the enzyme activities were compared with the control group using the paired sample $t$ test (SPSS for MAC, version 21.0.0.0).

\section{Results}

\section{Alignment Analysis of amv133}

The amino acid sequence of $a m v 133$ has a nucleophilic elbow (GXSXG motif, X = any amino acid) between the 176 th and 180th amino acid, which confers enzyme activity in lipases and esterases [9]. Also, it includes a putative catalytic triad, which contains serine, aspartic acid and histidine amino acid at position 178, 232 and 270 respectively, with a high overall degree of amino acid similarity to known lipases (fig. 1). Among these amino acid sequences, which are used in these alignments, only the lipase protein encoded by Rhizopus niveus and $H$. virescens ascovirus have been tested for lipase activity. It was determined that $H$. virescens ascovirus lipase is not active in 


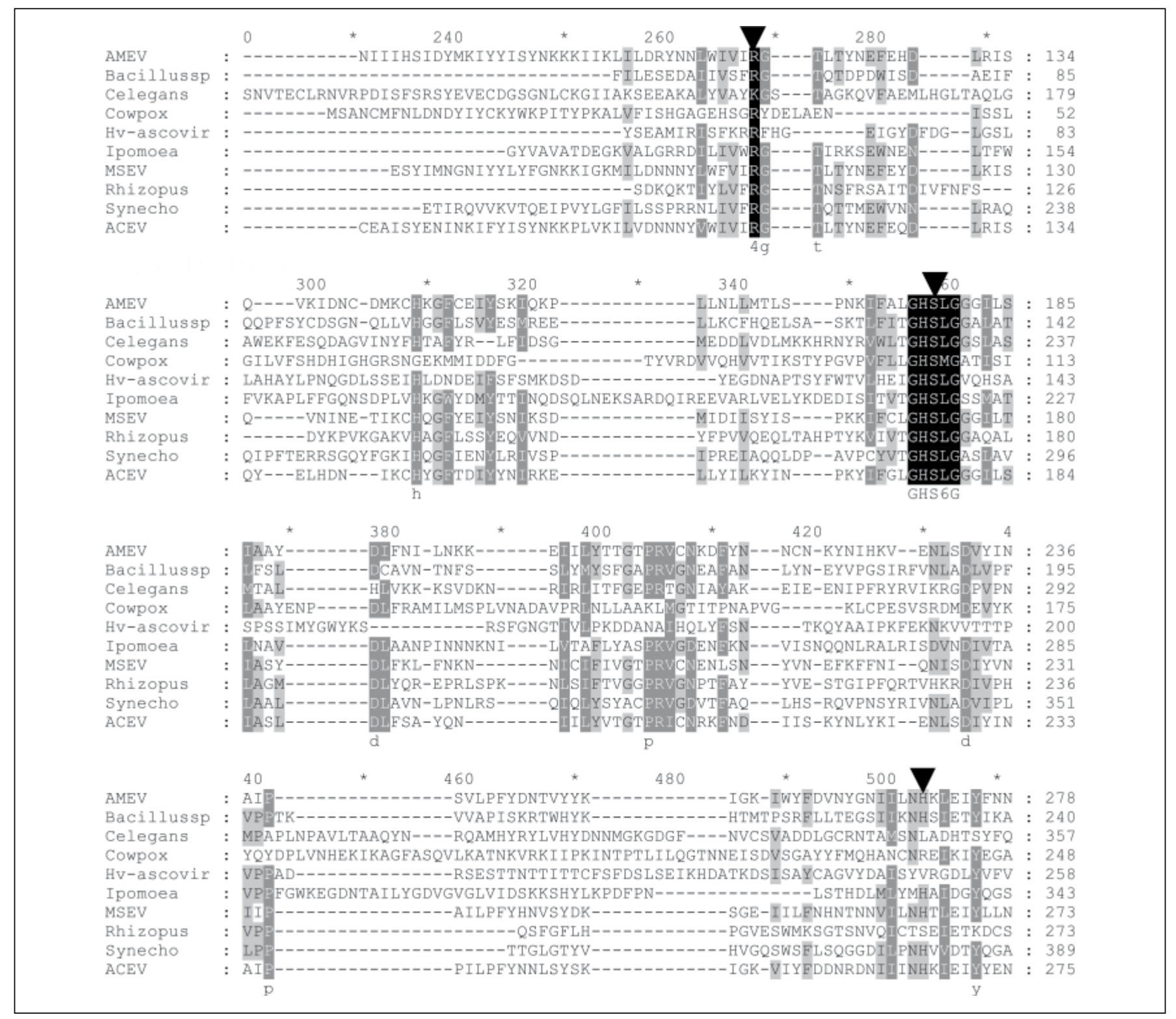

Fig. 1. Alignment of $a m v 133$ at the active site of triacylglycerol lipases. AMEV = Amsacta moorei entomopoxvirus, accession No. NP_064915.1; Bacillus sp = Bacillus sp., accession No. WP_010195194.1; Celegans = Caenorhabditis elegans, accession No. NP_504600.3; Cowpox $=$ CPV putative lipase, accession No. CAA64113.1; Hv-ascovir $=$ Heliothis virescens ascovirus, accession No. YP_001110872; Ipomoea = Ipomoea nil, accession No. U55867;

vitro [20] but that $R$. niveus has an active lipase [30]. The remaining proteins have not been tested for lipase activity in vitro yet.

amv133 was also aligned with 5 betaentomopoxviruses (fig. 2). There is a significant similarity between these entomopoxviruses. All of them include a conserved se-
MSEV = Melanoplus sanguinipes entomopoxvirus strain Tucson, accession No. NC_001993; Rhizopus = Rhizopus niveus, accession No. D12680; Synecho = Synechocystis sp., accession No. NP_442511.1; ACEV = Anomala cuprea entomopoxvirus, accession No. YP_009001656.1. The ExPASy-PROSITE signature is PS00120. Triangles indicate catalytic triad.

quence of GHSLG, which is a nucleophilic elbow, and a catalytic triad composed of serine, aspartic acid and histidine amino acid.

There was no significant similarity between the protein sequence of $a m v 133$ and known proteases. However, amv133 has the catalytic triad of serine proteases. 


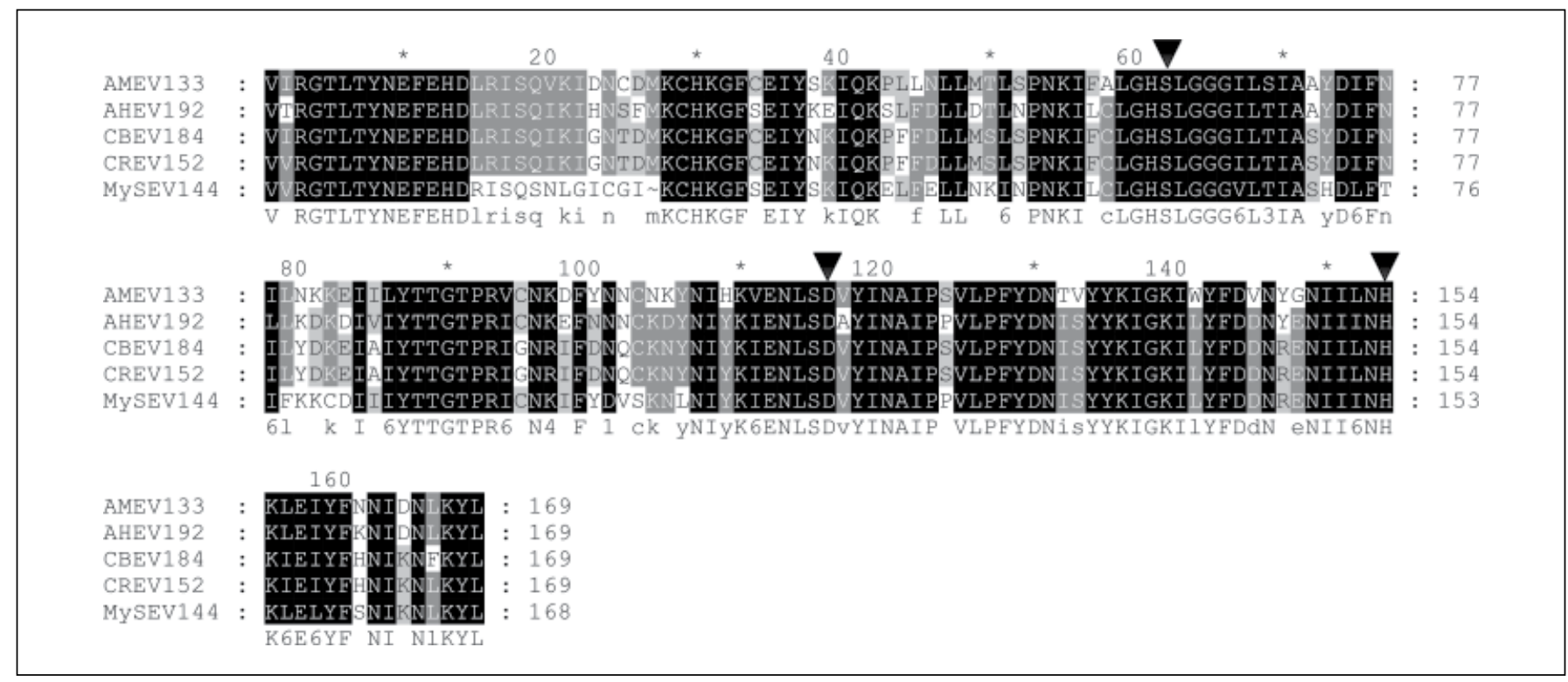

Fig. 2. Alignment of amv133 among betaentomopoxviruses. AMEV = Amsacta moorei entomopoxvirus ' $L$ ' strain Moyer, accession No. NC_002520; AHEV = Adoxophyes honmai entomopoxvirus 'L' strain Japan, accession No. HF679131; CBEV = Choristoneura biennis entomopoxvirus 'L' strain Canada, accession No.
HF679132; CREV = Choristoneura rosaceana entomopoxvirus ' $L$ ' strain Canada, accession No. HF679133; MySEV = Mythimna separata entomopoxvirus 'L' strain China, accession No. HF679134. The triangles indicate the catalytic triad.

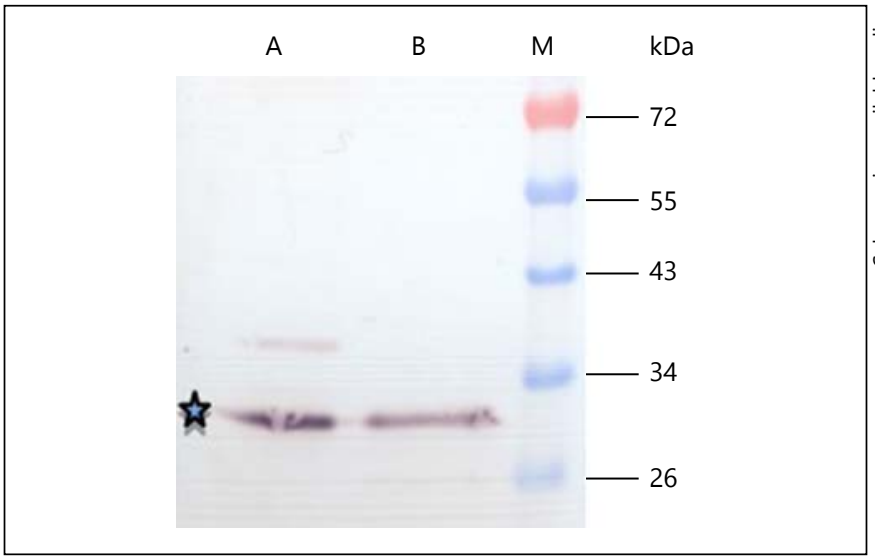

Fig. 3. Expression of amv133 in a bacterial expression system. The asterisk indicates an approximately $32-\mathrm{kDa}$ protein belonging to amv133. $\mathrm{A}=$ Unpurified protein of $a m v 133 ; \mathrm{B}=$ purified protein of amv133; $\mathrm{M}=$ molecular weight $(\mathrm{kDa})$.

\section{amv133 Encodes Functional Esterase Gene with Protease Activity}

To test the enzyme activity of $a m v 133$, a bacterial vector system (fig. 3 ) and a baculovirus vector system (fig. 4) were used to express amv133. Expressed protein was partially purified by using His-tag and used for enzyme as-

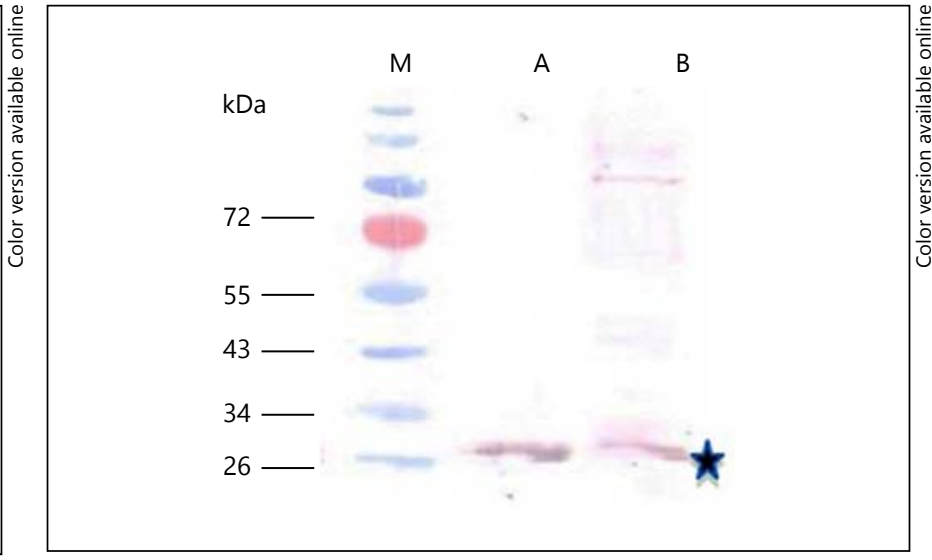

Fig. 4. Expression of amv133 in a baculovirus expression system. The asterisk indicates an approximately $32-\mathrm{kDa}$ protein belonging to $a m v 133 . \mathrm{A}=$ Purified protein of $a m v 133 ; \mathrm{B}=$ unpurified protein of $a m v 133 ; \mathrm{M}=$ molecular weight $(\mathrm{kDa})$.

say. For the negative control, a nonenzymatic $337 \mathrm{~L}$ gene of Chilo iridescent virus was also expressed in the same vectors and partially purified using His-tag. An equal amount of purified $337 L$ and $a m v 133$ were used for a lipase, esterase and protease activity assay. In the test results, amv133 did not show anylipase activity, but showed 
Fig. 5. Esterase activity of amv133 expressed in bacterial and baculovirus vector systems. Bars show standard errors. a Activity of the protein produced via a baculovirus vector system. b Activity of the protein produced via a bacterial vector system.
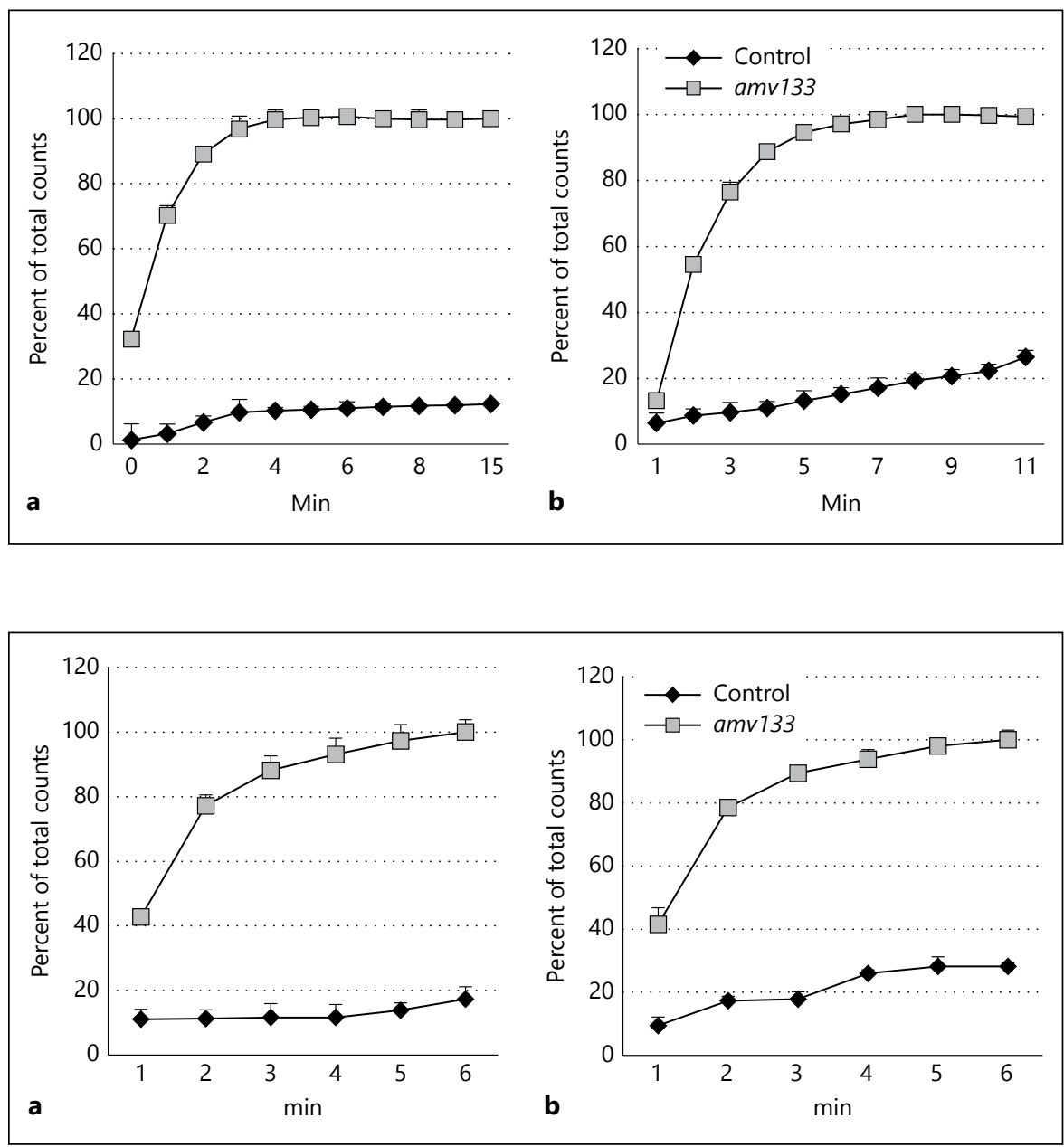

Fig. 6. Protease activity of amv133 expressed in bacterial and baculovirus vector systems. Bars show standard errors. a Lipase activity of the protein produced via a baculovirus vector system. b Lipase activity of the protein produced via a bacterial vector system. a 3.7- and 2-fold higher esterase activity than control groups in baculovirus and bacterial vector systems, respectively (fig. 5).

Protease activity of $a m v 133$ was 7.7 - and 2.9-fold higher than control protein expressed in baculovirus and bacterial vector systems, respectively (fig. 6). Protease activity can be inhibited in the presence of PMSF, which is a specific inhibitor of serine proteases [31]. Therefore, the results indicate that amv133 shows serine protease activity. Control and test results were compared statistically and showed that the results varied in comparison to the control group $(\mathrm{p}<0.05)$.

\section{Discussion}

So far, thymidine kinase [32], DNA topoisomerase [33], $\mathrm{NAD}^{+}$-dependent DNA ligase [34], superoxide dismutase [35], inhibitor of apoptosis [36, 37], p33 [38],
poly(A) polymerase [3] and DNA photolyase [39] genes of the AMEV have been functionally examined. In this study, we examined for the first time the lipase, esterase and protease activity of amv133 from AMEV.

We observed the GXSXG (X = any amino acid) motif, called the nucleophilic elbow, which contains lipase active serine amino acid in the amino acid sequence of amv133. This serine amino acid is also a component of the catalytic triad that is composed of serine, aspartic acid and histidine at the position of the 178th, 232nd and 270th residues of the amv133 amino acid sequences. These characteristics are found in lipolytic enzymes. The alignment between amv133 and known lipases indicates that the GHSLG motif was present in all aligned sequences (fig. 1). Furthermore, the catalytic triad was common not only to the lipases and esterases, but also to the known active center of serine proteases [9]. Based on the fact that some serine proteases exhibit lipase activity, protease assays were performed for amv133, and it was found that amv133 ex- 
hibits protease activity, too. The protease activity of amv133 can be inhibited in the presence of PMSF, and this shows that amv133 encodes a serine protease. amv133 also showed esterase activity, but not lipase activity.

AMEV replication takes place in various larval tissues, but it prefers fat body cells [5], which are the major site of lipid storage [6]. Lipids play an essential role on both the viral and the cellular sides and in key features such as virion structure, target membrane and cell receptor recognition, viral membrane fusion, viral replication, assembly, egress and entry [40]. Furthermore, the vaccinia virus carries an active lipase gene that is essential for membrane fusion and cell-to-cell transmission [14]. amv133 has lipolytic activity and thus it might also have such a function.

Furthermore, amv133 also shows protease activity. Viral proteases showed insecticidal activity by degrading the peritrophic matrix and increasing the speed of insect death $[23,24]$. amv133 may contribute to viral infection through such a function. Apart from this, a lipid-carrying protein (lipoprotein), apolipophorin, which inhibits the bacterial infection [41] and is one of the host immune-related proteins against virus infection [42], stimulates the immune activation [43] and is essential for lipid transport in insects for energy sources and/or lipid storage $[44,45]$. amv133 shows both esterase and protease activities, so it may have some functions to degrade these lipoproteins; therefore, viruses can escape from the host immune response and improve the infection.

\section{Conclusions}

In summary, amv133 shows esterase and protease activity and may be essential for membrane fusion, like in the case of the vaccinia virus lipase gene, or important for host immune modulation, as is suggested for the lipaselike genes of either Marek's disease virus [19] or ectromelia virus [21], by degrading lipoproteins. Our data raises the possibility that amv133-like genes may be such a component in entomopoxviruses.

\section{Acknowledgments}

The Scientific and Technological Research Council of Turkey, TUBITAK, supported this study with project No. 109T975.

\section{References}

1 Jankovich JK, Chinchar VG, Hyatt A, Miyazaki T, Williams T, Zhang QY: Iridoviridae; in King AMQ, Adams MJ, Carstens EB, Lefkowitz EJ (eds): Virus Taxonomy: Classification and Nomenclature of Viruses. Ninth Report of the International Committee on Taxonomy of Viruses. Amsterdam, Elsevier, 2011, pp 193-202.

-2 Thézé J, Takatsuka J, Li Z, Gallais J, Doucet D, Arif B, Nakai M, Herniou EA: New insights into the evolution of Entomopoxvirinae from the complete genome sequences of four entomopoxviruses infecting Adoxophyes honmai, Choristoneura biennis, Choristoneura rosaceana, and Cythimna separata. J Virol 2013; 87:7992-8003.

3 Becker MN, Todd TM, Moyer RW: An Amsacta moorei entomopoxvirus ortholog of the poly(A) polymerase small subunit exhibits methyltransferase activity and is non-essential for virus growth. Virology 2008;375:624636.

$\checkmark 4$ Perera SC, Wong P, Krell PJ, Arif BM: Expression of heterologous genes in the Amsacta moorei entomopoxvirus. J Virol Methods 2010;165:1-8.

5 Arif BM: Recent advances in the molecular biology of entomopoxviruses. J Gen Virol 1995; 76:1-13.
6 Ottaviani E, Malagoli D, Franceschi C: The evolution of the adipose tissue: a neglected enigma. Gen Comp Endocrinol 2011;174:14.

7 Bawden AL, Glassberg KJ, Diggans J, Shaw R, Farmerie W, Moyer RW: Complete genomic sequence of the Amsacta moorei entomopoxvirus: analysis and comparison with other poxviruses. Virology 2000;274:120139.

8 Godoy LC, Duquesne S, Bordes F, Sandoval G, Marty A: Lipases and phospholipases: methods and protocols; in Sandoval G (ed): Methods in Molecular Biology. New York, Springer Science and Business Media, 2012, vol 861.

9 Wong H: The lipase gene family. J Lipid Res 2002;43:993-999.

10 Brady L, Brzozowski AM, Derewenda ZS, Dodson E, Dodson G, Tolley S, Turkenburg JP, Christiansen L, Huge-Jensen B, Norskov $\mathrm{L}$, et al: A serine protease triad forms the catalytic centre of a triacylglycerol lipase. Nature 1990;343:767-770.

11 Fujii R, Nakagawa Y, Hiratake J, Sogabe A, Sakata K: Directed evolution of Pseudomonas aeruginosa lipase for improved amide-hydrolyzing activity. Protein Eng Des Sel 2005;18: 93-101.
12 Maruyama T, Nakajima M, Kondo H, Kawasaki K, Seki M, Goto M: Can lipases hydrolyze a peptide bond? Enzyme Microb Technol 2003;32:655-657.

13 Wankhade G, Majumdar, A., Kamble PD, Harinath BC: Mycobacterial secretory SEVA TB ES-31 antigen, a chymotrypsin-like serine protease with lipase activity and drug target potential. Biomed Res 2011;22:45-48.

14 Baek SH, Kwak JY, Lee SH, Lee T, Ryu SH, Uhlinger DJ, Lambeth JD: Lipase activities of p37, the major envelope protein of vaccinia virus. J Biol Chem 1997;272:32042-32049.

15 Girod A, Wobus CE, Zadori Z, Ried M, Leike K, Tijssen P, Kleinschmidt JA, Hallek M: The VP1 capsid protein of adeno-associated virus type 2 is carrying a phospholipase A2 domain required for virus infectivity. J Gen Virol 2002;83:973-978.

16 Grieger JC, Snowdy S, Samulski RJ: Separate basic region motifs within the adeno-associated virus capsid proteins are essential for infectivity and assembly. J Virol 2006;80:51995210.

17 Zadori Z, Szelei J, Lacoste MC, Li Y, Gariepy S, Raymond P, Allaire M, Nabi IR, Tijssen P: A viral phospholipase A2 is required for parvovirus infectivity. Dev Cell 2001;1:291302.
AMEV Encodes a Functional Esterase

(amv133) with Protease Activity
Intervirology 2015;58:41-48 DOI: $10.1159 / 000369018$ 
18 Canaan S, Zadori Z, Ghomashchi F, Bollinger J, Sadilek M, Moreau ME, Tijssen P, Gelb MH: Interfacial enzymology of parvovirus phospholipases A2. J Biol Chem 2004;279:1450214508.

19 Kamil JP, Tischer BK, Trapp S, Nair VK, Osterrieder N, Kung HJ: vLIP, a viral lipase homologue, is a virulence factor of Marek's disease virus. J Virol 2005;79:6984-6996.

20 Smede M, Hussain M, Asgari S: A lipase-like gene from Heliothis virescens ascovirus (HvAV-3e) is essential for virus replication and cell cleavage. Virus Genes 2009;39:409417.

21 Wall EM, Cao J, Chen N, Buller RM, Upton C: A novel poxvirus gene and its human homolog are similar to an E. coli lysophospholipase. Virus Res 1997;52:157-167.

-22 Afonso, CL, Tulman ER, Lu Z, Oma E, Kutish GF, Rock DL: The genome of Melanoplus sanguinipes entomopoxvirus. J Virol 1999;73: 533-552.

23 Harrison RL, Bonning BC: Proteases as insecticidal agents. Toxins 2010;2:935-953.

24 Gramkow AW, Perecmanis S, Sousa RL, Noronha EF, Felix CR, Nagata T, Ribeiro BM: Insecticidal activity of two proteases against Spodoptera frugiperda larvae infected with recombinant baculoviruses. Virol J 2010;7:143.

25 Reed LJ, Muench HA: A simple method of estimating fifty percent endpoints. Am J Hyg 1938;27:493-497.

26 Bradford MM: A rapid and sensitive method for the quantitation of microgram quantities of protein utilizing the principle of proteindye binding. Anal Biochem 1976;72:248-254.

-27 Novototskaya-Vlasova K, Petrovskaya L, Yakimov S, Gilichinsky D: Cloning, purification, and characterization of a cold-adapted esterase produced by Psychrobacter cryohalolentis K5T from Siberian cryopeg. FEMS Microbiol Ecol 2012;82:367-375.
8 Colen G, Junqueira RG, Moraes-Santos T: Isolation and screening of alkaline lipase-producing fungi from Brazilian savanna soil. World J Microbiol Biotechnol 2006;22:881885.

29 Muratoğlu H, Nalçacıoğlu R, Demirbağ Z: Transcriptional and structural analyses of amsacta moorei entomopoxvirus protein kinase gene (amv197, pk). Annals of Microbiology 2010;60:523-530.

30 Kugimiya W, Otani Y, Kohno M, Hashimoto $\mathrm{Y}$ : Cloning and sequence analysis of $\mathrm{cDNS}$ encoding Rhizopus niveus lipase. Biosci Biotechnol Biochem 1992;56:716-719.

31 Rendon-Ramirez A, Shukla M, Oda M, Chakraborty S, Minda R, Dandekar AM, Asgeirsson B, Goni FM, Rao BJ: A computational module assembled from different protease family motifs identifies PI PLC from Bacillus cereus as a putative prolyl peptidase with a serine protease scaffold. PLoS One 2013;8:e70923.

32 Gruidl ME, Hall RL, Moyer RW: Mapping and molecular characterization of a functional thymidine kinase from Amsacta moorei entomopoxvirus. Virology 1992;186:507-516.

33 Petersen BO, Hall RL, Moyer RW, Shuman S: Characterization of a DNA topoisomerase encoded by Amsacta moorei entomopoxvirus. Virology 1997;230:197-206.

34 Sriskanda V, Moyer RW, Shuman S: Nad+dependent DNA ligase encoded by a eukaryotic virus. J Biol Chem 2001;276:3610036109.

35 Becker MN, Greenleaf WB, Ostrov DA, Moyer RW: Amsacta moorei entomopoxvirus expresses an active superoxide dismutase. J Virol 2004;78:10265-10275.

36 Li Q, Liston P, Moyer RW: Functional analysis of the inhibitor of apoptosis (Iap) gene carried by the entomopoxvirus of Amsacta moorei. J Virol 2005;79:2335-2345.
37 Li Q, Liston P, Schokman N, Ho JM, Moyer RW: Amsacta moorei entomopoxvirus inhibitor of apoptosis suppresses cell death by binding Grim and Hid. J Virol 2005;79:36843691.

38 Means JC, Penabaz T, Clem RJ: Identification and functional characterization of $A M V p 33$, a novel homolog of the baculovirus caspase inhibitor $p 35$ found in Amsacta moorei entomopoxvirus. Virology 2007;358:436-447.

-39 Nalcacioglu R, Dizman YA, Vlak JM, Demirbag Z, van Oers MM: Amsacta moorei entomopoxvirus encodes a functional DNA photolyase (AMV025). J Invertebr Pathol 2010; 105:363-365.

40 Blaising J, Pécheur EI: Lipids - a key for hepatitis $C$ virus entry and a potential target for antiviral strategies. Biochimie 2013;95:96-102.

41 Hanada Y, Sekimizu K, Kaito C: Silkworm apolipophorin protein inhibits Staphylococcus aureus virulence. J Biol Chem 2011;286: 39360-39369.

42 Doremus T, Jouan V, Urbach S, Cousserans F, Wincker P, Ravallec M, Wajnberg E, Volkoff AN: Hyposoter didymator uses a combination of passive and active strategies to escape from the Spodoptera frugiperda cellular immune response. J Insect Physiol 2013;59: 500-508.

43 Weers PM, Ryan RO: Apolipophorin III: role model apolipoprotein. Insect Biochem Mol Biol 2006;36:231-240.

44 Arrese EL, Canavoso LE, Jouni ZE, Pennington JE, Tsuchida K, Wells MA: Lipid storage and mobilization in insects: current status and future directions. Insect Biochem $\mathrm{Mol}$ Biol 2001;31:7-17.

45 Van der Horst DJ, Rodenburg KW: Locust flight activity as a model for hormonal regulation of lipid mobilization and transport. J Insect Physiol 2010;56:844-853. 